\title{
A Study of Consumption Alienation in Updike's Works
}

\author{
Qingzheng Liu \\ College of International Studies, Southwest University, Chongqing, China
}

\begin{abstract}
Updike's works reflect the characteristics of contemporary American society. There are many descriptions of consumerism in his works. The purpose of this paper is to present the consumption alienation in Updike's works, to explore the survival predicament of people under the consumption alienation, and to point out its damage to the ecological environment.
\end{abstract}

Index Terms — consumption alienation, false needs, media, survival predicament

\section{INTRODUCTION}

After World War II, the economic center of western developed countries began to shift from the production field to the consumption field, and consumption became the goal and driving force of people's life. In the 1950s and 1960s, mass consumption society and consumerism culture began to take shape. At that time, politicians and ordinary people generally believed that consumption was the way to lead the country to prosperity, and that it was the embodiment of the rationality and superiority of the western democratic political system. In "Rabbit Tetralogy", Rabbit spends most of his life in sales promotion, first in Kroll's department store, and then selling Kitchenware and cars. Moreover, most of his relatives, colleagues and friends are engaged in the work related to sales promotion. For example, his father-in-law has been engaged in car sales all his life. His wife Janice once becomes a car saleswoman. Later, she studies the evening course in a University and hopes to become a real estate agent. Although his son Nelson was opposed by him before, he finally becomes a car salesman and replaces him as the head of the car shop, while Charlie is a car salesman all the time, Ronnie Harrison works in insurance marketing all his life, and so on. Some Chinese theorists believe that: "The consumer society is a social form that appeared in the middle and late western modern industrial society. It emerged together with the modern large-scale industrial production mode represented by Fordism."(Tao Dongfeng, 2013, p. 93) As for consumerism culture, Jameson points out: "New types of consumption; planned obsolescence; an ever more rapid rhythm of fashion and styling changes; the penetration of advertising, television and the media generally to a hitherto unparalleled degree throughout society......these are some of the features which would seem to mark a radical break with that older pre-war society in which high modernism was still an underground force." (1998, pp. 19-20)

Western countries entered the consumer society after World War II, and industrial mass production contributed to the emergence of consumerism to some extent. According to Marx, labor should be a free and conscious activity of human beings. Since the beginning of the 20th century, the industrial production represented by Fordism has greatly improved the labor productivity, but people have lost their free time in their work and they become workers who carry out simple and repetitive operations on the assembly line. This kind of labor seriously suppresses people's personality and freedom, hinders people's creativity, curiosity and independent thinking. Therefore, people hope to obtain freedom and happiness in leisure time to make up for the feeling of unfreedom, monotony and boredom suffered in alienated labor, which provides the soil for alienated consumption. On the one hand, consuming behavior can satisfy the pursuit of profit of production enterprises, and at the same time, it can partly compensate people's sense of loss and lack of creativity under alienated labor. The concept of "Consumption Alienation" originated from the Frankfurt School. Influenced by Marx's theory of labor alienation and György Lukács' theory of materialization, combined with the situation of contemporary capitalist society, this school put forward the theory of consumption alienation. On the basis of inheriting this concept, later ecological Marxism studied the impact of alienated consumption on the ecological environment. Ben Agger defines consumption alienation as: "Consumption alienation refers to the phenomenon that people strive to obtain goods in order to compensate for their monotonous, non-creative and often underpaid labor." (1991, p. 494) Agger believes that "alienated consumption" is the logical counterpart of "alienated labor", "the lack of freedom and intention of self-expression in labor will make people gradually become more and more weak and dependent on consumption behavior. (ibid, pp. 492-493) With the further development of industrial society, people's consumption is alienated, which seriously deviates from people's all-round development. The development of science and technology has brought abundant material products, but they also stimulated the expansion of people's desires. It makes people driven by desire, and they constantly ask for more material goods. Schiller says: "Necessity, however, is now ruling, and subduing the sinking human race to its tyrannical yoke. Practicality is the great idol of this era. All forces should serve it and all talents should respect it." (2012, p. 3) People who used to pursue spiritual freedom and integrity of personality have 
become "one-dimensional man" who only pursue abundant material consumption and endless material benefits. The ubiquitous existence of commodity economy has corroded people's psychology and led to the deviation of human nature. After getting rid of the plight of material scarcity, people fell into the bondage of spiritual crisis.

Suffering from alienation at work, people seek to find satisfaction in the realm of consumption. But modern people's leisure time is often used for consumption controlled and guided by advertisement, which has almost become the main significance of leisure time. Therefore, people put the accumulated money into the field of consumption, trying to make up for the loss of freedom in labor through the free choice in consumption, so as to achieve freedom in a way, and satisfy their desire for creation. In this way, the relationship between people and goods is completely reversed, and goods control people in turn. This has become one of the four stipulations of Marx's alienation: the alienation between the workers and the product of labor, that is, the product of labor, though created by the laborer, is not owned by the laborer, but becomes an alien power that governs the laborer. In this regard, William Morris also says: "Commerce was made for man, but that man was made for Commerce." (1973, p. 93)It is only in consumption that people experience temporary happiness, and soon they will be trapped in unfree labor again. And the lack of freedom at work is hard to compensate for with momentary pleasure.

Marx puts forward the concept of commodity fetishism in Das Kapital. In the world of commodity fetishism, people indulge in excessive consumption and fashion. In such a state of existence, the world of human being is replaced by the world of things. People realize their affirmation with the help of commodities and fashion, rather than through their self-initiative and conscious creativity. Similar to the alienation in production, people suffer from alienation in the world of commodity, resulting in the loss of human autonomy, subjectivity and self-reliance.

\section{UBIQUITOUS CONSUMPTION}

After World War II, the rapid development of American economy was based on the development of consumer society. In Rabbit, Run, Updike describes a contemporary American society in which consumerism culture is ubiquitous. The author juxtaposes Rabbit's dissatisfaction with his job, his discordant marriage life and the rampant consumption. The need for hard work on the one hand, and the need for seemingly worthless consumption on the other, is the cause of the cultural contradictions of capitalism, and is the cause of the breakdown of Rabbit's family. From the beginning, Rabbit has shown a kind of ominous anxiety (such as his name: Angst(fear)+Strom(Stream)=Angstrom, or "Stream of Fear". (Beckoff, 1974. p. 13)) which indicates the role and existence of material consumption.

In the novel, the influence of consumerism culture is reflected in many places. When Rabbit marries Janice, who comes from a middle-class family, his father-in-law, Mr. Springer, insists that he buy a Ford for 1000 dollars to replace his 1939 Nash, which Mr. Springer regards as a shame to his middle-class status, even though Rabbit is strapped for cash at the time. The change from Nash to Ford is an important symbol of the shift to consumerism. This makes Rabbit affected by the mainstream consumerism culture from the beginning of his marriage. Furthermore, Rabbit's job is selling peelers in retail stores, which is the embodiment of consumerism.

After returning home from work, Rabbit finds Janice watching TV commercials (interestingly, she turns it off when the news comes on). She is obviously drunk and smelled of alcohol while watching the TV commercial, and then she asks Rabbit for a cigarette. This shows different kinds of consumption, as well as the irrepressible impulse to consume. During the day, she goes shopping with her mother at the Kroll mall and buys a scarf at a sale. Even though it is March, she also buys a bathing suit. Rabbit is surprised and says: “A bathing suit! Chh. In March?” (Updike, 2003. p. 6) All these consumption activities by Janice exacerbates Rabbit's aversion. What is shown here is a disharmonious scene, which connects various consumption situations to explain why Rabbit runs away from home. Another profound fact is that the last thing Janice tells him before he leaves and abandons her is to buy cigarettes. This is the last straw that crushes Rabbit. Later, when Eccles asked why Rabbit had left his family, he replied frankly: "She asked me to buy her a pack of cigarettes." (ibid, 2003. p. 104) This provides a new clue to explain Rabbit's unharmonious marriage, and helps to understand Updike's other social views. What's significant is that Rabbit met Janice and married her while they were working at the Kroll mall. At that time, she worked as a saleswoman selling candy and cashews while he worked upstairs, moving furniture and dismantling packing cases. None of the employees liked their work at the Kroll mall. After work from the mall, Rabbit and Janice often meet to have sex in their friends' apartment, so as to get rid of the boredom at work. Rabbit, run is shrouded in the contradiction between the alienation of the nature of work and the expanding role of consumption in American life, and these contradictions appear in the capitalist society during the period of industrial production. Yoav Fromer comments on this: "What Daniel Bell would label 'The Cultural Contradictions of Capitalism' nearly two decades later, begins to take shape and breakup the American family on the pages of Rabbit, Run." (2014, p. 179)

In addition, a large number of advertisements appearing in the novel constantly arouse the consumption desire of the characters in the novel, make people form a new concept of consumption, and make consumerism continue to affect people's daily life. During Rabbit's initial escape, the car drives far away. The radio in the car is still a variety of advertisements, and various billboards are erected on both sides of the highway. These advertisements concern all aspects of life. They constantly invade into Rabbit's life, so he is stimulated by advertisements all the time. No matter where he goes, all he can see are advertisements, which disappoint him a lot. This shows that even if Rabbit runs away from home, there are certain things - such as consumption - that he can't escape. It seems that he can't escape this huge 
net of consumption in any case. The only thing he feels comfortable on that journey is when he notices that there are no commercials on the radio and the music is soothing and lyrical. Alienated consumption causes people's souls to be corroded, leads to the deviation of human nature, and makes people suffer from "material abundance and spiritual pain".

Later, when her father calls and asks "Did Rabbit run again?" Janice does not admit the truth, but makes up a lie that Rabbit had gone to work "to sell cars." Not only did Rabbit not go to work in the morning - which might have prevented his daughter's death - but to make matters worse, he actually went shopping. The novel clearly tells us that Rabbit spent the day, "going in and out of department stores with music piping from the walls and eating a hot dog at the five and dime and hesitating outside a movie house." Although "he has a sense of ominous feeling that things are wrong", he chooses to walk along the gate of the cinema, walking between the perfume underwear cabinet, small jewelry and salt nut cabinet. And his initial reaction to the tragic news is also related to the fact of consumption: He doesn't know what he says to Eccles; all he is conscious of is the stacks of merchandise in jangling packages he can see through the windows of the phone-booth door. (Updike, 2003, pp. 271-273) Throughout the novel, Rabbit reveals a consumer-centric culture, which replaces Protestant professional ethics. For a long time, he and Janice have immersed in consuming a large number of goods and services brought by the industrial society, rather than engaging in work that is personally meaningful. The progress of science and technology and the development of production have brought a large number of material products to the society, but people's desire is also expanding constantly, and they try to possess more and more consumer goods. In that case, the person who originally pursues the spiritual freedom and integrity of personality will degenerate into a "one-dimensional man" who only pursues endless material interests. Although there are many reasons for the breakdown of Rabbit's family, the consumerism culture of post-war capitalism is also one of them.

In recent years, research by American historians have enriched the historical outline described by Updike in Rabbit, Run. Economic factors infiltrate into political field, especially the field of culture, and they have a profound impact on family and social structure. The most striking description of this phenomenon is Alan Brinkley, who has described the postwar era as "a world in which both the idea and the reality of mass consumption were becoming central to American culture and to the American economy, gradually supplanting production as the principal focus of popular hopes and commitment." (1995, p. 4) He concludes that "In an economy driven by consumer spending, it is not surprising that political thought began to reflect consumer-oriented assumptions as well." (ibid, p. 10) Lizabeth Cohen has similarly argued that "a Consumer's Republic" was forged during these years in which "mass consumption had become a central defining engine, not simply of the American economy but of its politics and culture as well." (2003, pp. 7-11) Brinkley and Cohen lament the political significance of economic transformation and the decline of Republican virtue, which is crucial to American liberalism in the following decades. In Rabbit, Run, Updike uses his literary imagination to raise similar concerns and warn of the potential danger they pose to families. People are immersed in the ocean of consumption and affected by alienated consumption, resulting in the loss of their own autonomy, subjectivity and self-reliance.

\section{THE INFLUENCE OF ALIENATED CONSUMPTION}

The problem of consumption alienation that Updike describes in Rabbit, Run will continue to run through his other works. Before he makes consumption alienation one of the themes of Rabbit is Rich, Updike evaluates the impact of material consumption on American society and individuals in some early and important short stories and essays, including $A \&$ \& , Farewell to the Middle Class, Domestic Life in America, and The Bankrupt Man.

$A \& P$ was written in the 1960 s, when the American society was in the period of economic rise and consumerism was rising in the whole society, and all kinds of consumption places and behaviors were influenced by consumerism culture. The world's first supermarket was born in the United States in the 1930s, and it became a symbol of the consumer society. In the 1950s and 1960s, supermarkets around the world developed rapidly. In this short story, Updike sets the scene in the A \& P supermarket. A \& P, the Great Atlantic and Pacific Tea Company, is a chain supermarket and liquor store in the United States. It is one of the most popular and dominant supermarkets in American history, and it is headquartered in Montville, New Jersey. The Atlantic \& Pacific Tea Company owns a chain of supermarkets in several states: Connecticut, Delaware, Maryland, New Jersey, New York and Pennsylvania. A \& P began operations in 1859 and had about 200 stores selling tea, coffee, and selected groceries by 1900. (Blackford, 2003, p. 65) By 1929, A \& P operated 15,418 stores, and operated 14,926 grocery stores in 1935 . In 1951, the company boasted sales of nearly $\$ 3.2$ billion and profit of $\$ 32$ million. (ibid, pp. 108-110)

The variety of commodities in supermarkets, the monotonous work of cashiers and the numbness and tameness of customers described in $A \& P$ are the typical living conditions of American consumer society in the 1960s, which is an aspect of people's daily life at that time. Updike chooses A \& P supermarket as the scene of the story, which has his own unique features. The name "Atlantic and Pacific" stands for the whole of the United States, which stretches from the Atlantic to the Pacific, so it is the symbol of the whole United States. A \& P is a supermarket, which is used by the author to illustrate that the background of the story is the American society where consumerism is rising. This reflects his view of the world held by the author in his other works, that is, using a small shopping mall or a small poorhouse to describe a big society. His first novel, The Poorhouse Fair, condenses the world into a small courtyard and turns it into 
a marketplace for consumption.

In A \& P supermarket, people can choose and buy the goods they like at will. As a place of consumption, A \& P supermarket arranges goods according to the principle of convenient consumption and even guiding consumption. In order to highlight the image of commodity economy represented by the supermarket, the author intentionally strengthens the description of the layout of the shopping mall and the display of goods, listing them in detail, involving more than 20 kinds of goods. The modern equipment, neatly arranged shelves and commodities in the supermarket together create a neat, reasonable and orderly consumption place. In this short story, the author lists in detail rows of food shelves and all kinds of goods that the customers bought. This list not only outlines the layout of the mall, but also gives a sense of on-site. In this supermarket, there are different kinds of food, such as milk, macaroni and raisins, seasonings such as sauces and butter, drinks and snacks, as well as animal food such as cat food and dog food. Furthermore, Modern equipment, such as air conditioning, lighting, plastic flooring and electronic eyes, create a modern atmosphere for the customers.

The rationalization mode of consumer society makes people's choice have the characteristics of standardization, which is similar to the alienation in the production process. In the consumer society, consumers have become the victims of consumerism and the objects of slavery. The customers in A \& P supermarket can be said to be the concentrated embodiment of consumption alienation. When they go shopping, they behave in a regular and dull way, and they only focus on their own shopping behavior. When the manager scolds the three bathing-suit girls for their clothes, they show indifference. It seems that they have nothing in mind but consumption, and they lose their thinking ability and creativity. In Sammy's eyes, customers in the supermarket are as tame as sheep, and he uses the word "sheep" many times to describe them. These customers repeat the mechanical operation and rules in the production process when they are shopping. They lack their own independent judgment, and their individual autonomy and independence disappear in the consumption activities. In this short story, Updike makes such a description: "The sheep pushing their carts down the aisle...... A few houseslaves in pin curlers even looked around after pushing their carts past to make sure what they had seen was correct." (2003, pp. 597-8) In Sammy's eyes, these customers become a tame group, which has been alienated by the consumer society. Meanwhile, the labor process is standardized in the era of industrial mass production, so the products produced are the same, without any personality. As Fromm says: "It needs men who co-operate smoothly in large groups; who want to consume more and more, and whose tastes are standardized and can be easily influenced and anticipated. It needs men who feel free and independent, not subject to any authority, or principle, or conscience-yet willing to be commanded, to do what is expected, to fit into the social machine without friction." (2008, p. 107)

In A \& P supermarket, not only people's choices are characterized by standardization, but also people themselves are alienated into a kind of commodity. Sammy is very fond of the three girls who go into the supermarket, and he makes a careful observation of them. He likens the objects in the supermarket to their body parts: the buttocks of the first girl walking ahead of them to two sweet cans, the face to berry, Queenie's hair to a bun that was unravelling, and her breasts to the two smoothest scoops of vanilla. Sammy materializes these girls. In his eyes, "They are like commodities, just objects that are watched, touched and used." (Thompson, 2001, p. 216) Under the influence of consumerism culture, people turn all objects into objects for consumption, commercialize all objects, and even people themselves are materialized. In other words, alienation has spread from the field of production noted by Marx to the field of consumption, forming the alienation of consumption.

At the same time, in the process of consumption, the customer's status is related to shopping. Queenie buys canned herring, from which Sammy speculates their family's financial situation and guesses that they should belong to the upper class. After being scolded by the manager for wearing bathing-suit, the first girl argues: "We weren't doing any shopping. We just came in for the one thing." (Updike, 2003, p. 600) The dialogue between that girl and the manager shows a phenomenon that pervades the consumer society, that is, customers' consumption behavior becomes orderly, and customers' "dignity" is reflected in the price and quantity of the goods they buy or whether they buy the goods. They live in a society where consumerism prevails, where consumers are measured by what they buy. In fact, people tend to lose themselves in the pursuit of material satisfaction, thus losing their independence and autonomy. That is because people in the pursuit of material satisfaction are within the scope of social management system, and they accept the social constraints imposed on them. In this case, the more material satisfaction people get, the more constraints they will be subject to.

At the same time, customers in A \& P supermarket regard many items with little practical value as their real needs. In front of the cash register, an old man in baggy grey pants buys four huge cans of pineapple juice, for which Sammy is very surprised. He doesn't know what these idle people are doing with so much pineapple juice. These are all false needs, which are non-essential needs imposed on individuals from the outside. For false need, Marcuse defines it as follows: "'False' are those which are superimposed upon the individual by particular social interests in his repression: the needs which perpetuate toil, aggressiveness, misery, and injustice." (2002, p. 7) According to Marcuse, false needs are created by the society and transmitted to consumers by external public opinion, but these needs are not the real needs of consumers. He says: "Most of the prevailing needs to relax, to have fun, to behave and consume in accordance with the advertisements, to love and hate what others love and hate, belong to this category of false needs." (ibid, p. 7) Daniel Bell has a similar argument about needs and real needs. He mentions the classical distinction between needs and 
wants: "Needs are what all individuals have as members of the 'species'. Wants are the varied desires of individuals in accordance with their own tastes and idiosyncrasies. I believe that the first obligation of a society is to meet those essential needs; otherwise, individuals cannot be full 'citizens' of the society." (1978, p. xiii)Therefore, it can be said that the false need is not generated by the real needs of individuals, but is instilled into the members by the consumer society, and individuals living in such a society can only be passively affected by it. Perhaps the old man's purchase of four cans of pineapple juice has a real use for it, but Sammy's comment on the whole illustrates that sometimes customers buy products not for their real needs, but may be the result of the influence of consumerism. This has made the individual increasingly dependent on material things, and they are completely dominated by material consumption. In this process, people lose their own subjectivity, fall into the ocean of material consumption, and their spirit becomes more and more single and painful. This is a new type of control over people by consumption in the late capitalism, so people are reduced to one-dimensional man. Thus, such consumption can not make people realize their self-worth, let alone realize their own freedom and liberation.

\section{The Role of Media in Consumption Alienation}

The story of Rabbit is rich happened in the late 1970s and early 1980s, when consumerism flourished in western developed countries. With the help of advertising and other media, enterprises constantly instill consumerism culture into people's mind, which makes people's consumption of goods become an important feature of consumer society. This culture eventually makes consumerism become the mainstream of people consumption life, and it penetrates into all fields of social life. This novel describes a variety of commodities, media and consumption behavior, showing a strong feature of consumerism. In contemporary society, media has become an important factor of consumerism culture, or in other words, consumerism culture is based on media. The media in Rabbit is Rich exists in many forms, such as visual, auditory and video. Rabbit's consciousness and views are greatly influenced by newspaper news and commercial advertisements on TV. He often reads Consumer Reports in his spare time, regards it as a new Bible, and buys things according to the information on it. From the perspective of social culture, Rabbit's consumption behavior is of great significance, that is, the prevailing consumption culture in contemporary American society. As a person living in society, Rabbit can not get rid of the influence of social culture. What Nelson says to Rabbit may be a typical example: "What you don't realize about a consumer society, Dad, is it's all fads in a way. People don't buy things because they need'em. You actually need very little. You buy something because it's beyond what you need, it's something that will enhance your life, not just keep it plugging along." (Updike, 1990, pp. 456-457) In this regard, Agger has a similar view: "The good life is defined in terms of present levels and styles of attainability, not in terms of qualitatively different criteria of maximal social justice as well as a benign relationship to nature."(1992, p. 144) This is because the contemporary capitalist society instills consumerism values into people's mind, which makes people's values change.

Due to the long-term influence of various types of media, Rabbit accepts the consumerism culture advocated by the consumer society. Especially after he becomes rich, he begins to pursue material goods and pleasure. In the novel, TV programs are full of advertisements that encourage consumption, which gives Rabbit an impulse to eat out and consume, so as to become a real consumer like anyone else in American society. Toyota Motor Company has a lot of advertisements on TV, roadside and other places, which constantly stimulate people. Under the influence of advertising and other factors, the sales volume of Toyota in Springer Motors has increased greatly, and the operators of auto companies like Rabbit are also using advertising to attract people's attention and attract customers. Rabbit himself is a salesman, and he also spreads consumerism culture to customers at work. He asks the client: "Who in this day and age keeps a car much longer than four years?" (Updike, 1996, p. 8) All these show the strong color of consumerism in the novel and reveal the influence of consumerism on Rabbit himself.

As a member of the consumer society, Rabbit reads Consumer Reports regularly, so he can cater to new cultural tastes. Rabbit communicates with his middle-class friends based on the information provided by Consumer Reports, which becomes a symbol of his status. In Consumer Society, Jean Baudrillard says: "Just as medieval society established balance through God and devil, our society established balance through consumption and revelation."(2000, p. 231) This is because modern enterprises use a variety of methods to arouse people's desire for consumption, one of which is to promote "equal consumption", that is to say, in the purchase of a certain commodity, all consumers are equal, no matter what kind of identity consumers are, and they can equally consume goods. People believe that equal consumption is a new form of democracy. Through the consumption of goods, capitalist societies create an illusion for consumers that everyone is equal before consumption. In such an illusion, the real development of human beings can not be realized, and the initiative of human beings is also covered by the complacency in consumption. Rabbit and his middle-class friends often exchange different kinds of economic information, play golf, talk about kinds of consumer topics. For this kind of things, Daniel Bell has such a discussion: "Getting ahead is no longer a matter of rising up a social ladder, as it was in the late nineteenth century, but of adopting a specific style of life — country club, artiness, travel, hobbies - which marks one as a member of a consumption community."(1978, p. 68) Rabbit is fascinated by the performance of various types of electric can openers, air conditioners and fans in Consumer Reports. It's all as Daniel Bell says: "In effect, culture, as it came to be conceived in the mass middle-class magazines, was not a discussion of serious works of art but a style of life that was organized and 'consumed." (ibid, p. 44)

In Rabbit is Rich, the main function of food and diet is to highlight the destructive potential of consumption. Rabbit's 
wealth enables him to consume large amounts of resources, such as food and gasoline. At the beginning of the novel, Updike takes food as the symbol of all natural resources. When Rabbit and Charlie discuss the oil shortage, he says: “These kids coming up, they'll be living on table scraps. We had the meal."(Updike, 1996, p. 5) Later, in the novel, all kinds of unconscious eating behaviors represent the consumers' indifference to the impact of consumption on environment. Consumption alienation leads to the exhaustion of natural resources and the destruction of ecological environment, because the prosperity of consumer society is at the cost of exhausting resources, which leads to the deterioration of the relationship between man and nature.

Rabbit's soul is empty. He is attracted by all kinds of better and newer goods. He always wants to own more goods, so he keeps buying more and more things. Only by continuous consumption can he temporarily leave the feeling of emptiness and powerlessness, and get the value of existence. There is an alienated relationship between Rabbit and commodities: Although labor products are created by laborers, they are not owned by laborers, but becomes an alien power that controls the laborer. Rabbit inherits the old Springer and becomes the owner of the Springer Motors. He has his own property and could run the car shop in his own way, realizing independence and autonomy in his work. At the same time, in the traditional sales mode, he can play his own initiative and creativity. However, he is still restricted by consumption alienation. His consumption still maintains and consolidates the alienation in the whole production field. The field of consumption has become a source of crisis in modern capitalism. Agger believes that: "Marx's theory of alienated labor can no longer be used alone to analyze the crisis trend of modern capitalism." (1991, p. 486) And "In particular, they don't pay attention to the possibility of transforming the consumption field, and mistakenly believe that once the alienation in the production field is eliminated, people's needs can be freely expressed and satisfied." (ibid, p. 499) André Gorz says that the reduction in working hours alone cannot lead to liberation: "If free time is to become a condition for emancipating and realizing people's all-round development and socialism, there must be collective facilities that can provide a space for people's communication and autonomous activity, and there must be a non-market, voluntary and cooperative exchange and production system." (1985, p. 103) Thus it can be seen that Rabbit's selling Toyota cars in the car shop still belongs to "paid labor". Sales is a part of the social division of labor. Rabbit's leisure time is also controlled by economic rationality, as he goes shopping, and buys gold and silver. Therefore, Rabbit has not been able to escape the influence of consumption alienation.

\section{CONCLUSION}

The rise of consumerism comes at the cost of the deteriorating ecological environment and the exhaustion of natural resources. It endlessly meets people's needs and uses more consumer goods to ease their emptiness. However, this vicious circle has led to more rapid depletion of resources and serious damage to the environment. On the one hand, the scale of production is expanding day by day, the human need for energy is increasing, and there is more and more exploitation of natural resources. So it's an unsustainable mode. As Alan Thein Durning says: "The furnishings of our consumer life-style - things like automobiles, throwaway goods and packaging, a high-fat diet, and air conditioning - can only be provided at great environmental cost. Our way of life depends on enormous and continuous inputs of the very commodities that are most damaging to the earth to produce: energy, chemicals, metals, and paper."(1992, p. 52) On the other hand, capitalists use advertising media, commodity display and other marketing means to stimulate people's consumption need, guide consumers to further expand their demand, so that human demand for goods far exceeds their real needs. In addition, alienated consumption makes people ignore the alienation in labor to a certain extent, and alienates the relationship between human and nature, which makes human essence lose an important dimension and deviate from the "whole man". According to Agger, the ecological crisis based on consumption crisis has turned into the main crisis of post-war Western capitalism. As Marcuse says: "what is at stake in the socialist revolution is not merely the extension of satisfaction within the existing universe of needs, nor the shift of satisfaction from one (lower) level to a higher one, but the rupture with this universe, the qualitative leap. The revolution involves a radical transformation of the needs and aspirations themselves, cultural as well as material; of consciousness and sensibility; of the work process as well as leisure.” (1972, pp. 16-17)

Under the influence of consumerism, people are restricted by the laws of commodity economy, and the alienation of production process is repeated in consumption. People lose their autonomy, subjectivity and self-reliance, and become animals without their own thoughts and personalities. Meanwhile, consumption alienation leads to the continuous deterioration of the ecological environment and the estrangement between man and nature. The direct cause of ecological crisis is consumption alienation, which requires to change this consumption mode. However, because the alienation of labor is the social cause of consumption alienation, the most fundamental solution is to reform the production process, and then replaces the capitalist economic model of "producing more and consuming more".

\section{REFERENCES}

[1] Agger, B. (1991). Western Marxism: An Introduction. Trans. Shen Zhi, et al. Beijing: China Renmin UP.

[2] Agger, B. (1992). Cultural Studies as Critical Theory. London: The Falmer Press.

[3] Baudrillard, J. (2000). Consumer Society. Trans. Liu Chengfu et al.. Nanjing: Nanjing UP.

[4] Beckoff, S. (1974). John Updike's Rabbit, Run and Rabbit Redux: A Critical Commentary. New York: Monarch Press.

[5] Bell, D. (1978). The Cultural Contradictions of Capitalism. New York: Basic Books, Inc., Publishers. 
[6] Blackford, M. G. (2003). A History of Small Business in America. Chapel Hill and London: the University of North Carolina Press.

[7] Brinkley, A. (1995). The End of Reform: New Deal Liberalism in Depression and War. New York: Alfred A. Knopf.

[8] Cohen, L. (2003). A Consumer's Republic. New York: Vintage.

[9] Durning, A. T. (1992). How Much Is Enough? The Consumer Society and the Future of the Earth. New York and London: $\mathrm{W} \cdot \mathrm{W} \cdot$ Norton \& Company.

[10] Fromer, Y. (2014). Man in the Middle: The Political Imagination of John Updike and the Decline of Postwar Liberalism. Ann Arbor: ProQuest LLC..

[11] Fromm, E. (2008). The Sane Society. London and New York: Routledge.

[12] Gorz, A. (1985). Paths to Paradise: On the Liberation From Work. London: Pluto Press.

[13] Jameson, F. (1998). Cultural Turn. London. London· New York: Verso.

[14] Marcuse, H. (1972). Counterrevolution and Revolt. Boston: Beacon Press.

[15] Marcuse, H. (2002). One-Dimensional Man. London and New York: Routledge.

[16] Morris, W. (1973). Art and Socialism, Political Writings of William Morris. A. L. Monton, ed,. New York: International Publishers.

[17] Schiller. (2012). The Book of Aesthetic Education. Trans. Zhang Yuneng. Nanjing: Yilin Translation Publishing House.

[18] Tao Dongfeng. (2004). Aestheticization of daily life and discipline reflection on the Theory of literature and art. Tianjin Social Sciences. 4, 92-101.

[19] Thompson, C. E. (2001). Updike's “A \& P”. The Explicator. 4, 215-216.

[20] Updike, J. (1990). Rabbit at Rest. New York: Rosetta Books LLC.

[21] Updike, J. (1996). Rabbit Is Rich. New York: Random House Trade.

[22] Updike, J. (2003). A \& P. The Early Stories: 1953-1975. New York: Alfred A. Knopf. 596-601.

[23] Updike, J. (2003). Rabbit, Run. New York: Rosetta Books, LLC.

Qingzheng Liu was born in Chongzuo, China in 1980. He received his Master degree in English Language and Literature from Guangxi Normal University, China in 2008.

$\mathrm{He}$ is currently a Ph.D. candidate in English Language and Literature at College of International Studies, Southwest University, Chongqing. And he is currently a lecturer in School of Foreign Studies (School of International Education), Hezhou University, Hezhou. His research interests are American literature and English literature. 